\title{
Peculiarities of Young Schoolchildren's Reactions to their Success or Failure in Educational Activities
}

\section{Особливості реакцій молодших школярів на успіх і неуспіх у навчальній діяльності}

\section{Iryna Yavorska-Vietrova}

Ph.D. in Psychology, Senior Researcher, Senior Researcher of the Chamata Laboratory of Psychology of Personality, G.S. Kostiuk Institute of Psychology, the National Academy of Educational Sciences of Ukraine, Kyiv (Ukraine)

ORCID ID: https://orcid.org/0000-0002-6509-930X

Researcher ID: http://www.researcherid.com/rid/G-4702-2018 E-mail: irinavetrova009@gmail.com

\section{Ірина Яворська-Ветрова}

Кандидат психологічних наук, старший науковий співробітник, старший науковий співробітник лабораторії психології особистості імені П.Р. Чамати, Інститут психології імені Г.С. Костюка, Національна академія педагогічних наук України, м. Київ (Україна)

\section{ABSTRACT}

The aim of the research is to analyze the peculiarities of young schoolchildren's reactions to success or failure if they have different academic achievements.

Methods of the research. In order to investigate reactions to successes and failures characteristic for primary school children having different levels of academic achievements, the "Unfinished Sentences» technique was used.

Address for correspondence, e-mail: kpnu_lab_ps@ukr.net Copyright: (C) Yavorska-Vietrova Iryna

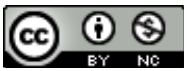

The article is licensed under CC BY-NC 4.0 International (https://creativecommons.org/licenses/by-nc/4.0/)

(C) Yavorska-Vietrova Iryna

DOI (article): https://doi.org/10.32626/2227-6246.2021-53.355-380 
DOI: https://doi.org/10.32626/2227-6246.2021-53

2021. випуск 53

The study covered schoolchildren of the second-fourth forms of primary school. Depending on their academic achievements, the studied schoolchildren were divided into three groups: with high, medium and low educational achievements.

The results of the research. The article shows that the most common reaction to success is a positive emotional experience and expectation of reward. The schoolchildren with low educational achievements even in case of success act in a non-constructive manner, their self-control skills are not developed enough, which provokes "background" undifferentiated anxiety. The schoolchildren characterized by often failure (low academic achievements) or often success (high academic achievements) react almost equally to failure: they show negative, particularly aggressive, reactions. At the same time, with the increase of children's age, schoolchildren form more constructive behaviour in situations of failure; we recorded their attempts to solve problems actively and effectively. The expediency to involve parents in the system of corrective and developmental influences on their children in order to ensure their constructive personal development is substantiated. The principles and rules of effective parent-child interactions are proposed.

Conclusions. The study of such a psychological phenomenon as the level of aspirations at different ages, and especially at primary school age, is of particular importance. This is necessary to develop individualised tactics of psychological influences and thereby to promote each child's harmonious personal growth. Differences between aspirations and opportunities, success or failure in different activities have a significant impact on a child's perception of his/herself, his/her self-assessment, and also on effectiveness of his/her activities, in particular, his/ her learning. Our research has determined that children experiencing academic failure for a long time become indifferent to learning, their emotions toward learning become negative, learning loses personal significance, and therefore, children do not feel responsible for own academic results. Taking into account the individual and group characteristics of primary school children with different academic achievements, reliance on the above-mentioned principles and rules of interactions will allow teachers and psychologists to choose optimal forms and methods of corrective work with such children and their parents.

Key words: primary schoolchildren, levels of academic achievements, reaction to success / failure, parents, parent-child interactions. 


\section{Introduction}

The personalized approach to education, understanding of a schoolchild as an integral personality, which is a source of his/her dignity and value (Król 2014), revealing of potential capabilities of each child, stimulating his / her inner activities, when a student remains an agent of his/her own development and activities (Maksymenko \& Serdiuk, 2016) are possible only on the basis of a deep and many-sided study of a child's personality, the system of his/her attitudes, including ones toward learning, people around him/her, and him/herself. Information about such personal characteristics that reveal most fully these attitudes is really important. An individual's level of aspirations is of particular importance.

In order to make a sufficiently complete picture of an individual's aspirations, it is necessary not only to reveal their character and peculiarities, but also to identify those factors that determine their level. Achievements that an individual has, their stability, the individual's self-assessment and his/ her evaluation by others ultimately lead to the formation of certain perceptions of him/herself, own capabilities and characteristics, goals and life aspirations, which means a certain level of aspirations (Бороздина, 2011; Дмитрієва \& Бутузова, 2016; Зинько, 2006; Меднікова, 2002; Ушакова \& Курбанов, 2011; Janke \& Dickhäuser, 2019). These perceptions determine an individual's behaviour, forcing him/her to maintain achievements at a certain level, accustomed to the individual.

It should be noted that a level of aspirations is manifested most clearly in a significant activity. Activity significance («Self-inclusion») is determined by a degree with which this activity brings an individual closer to his/her life plans and intentions, satisfies his/her needs, in particular those on which the individual's self-concept depends. R. Holt, by studying dependence of a level of aspirations on Self-inclusion and achievement motivation, experimentally proved that if Self-inclusion

(C) Yavorska-Vietrova Iryna

DOI (article): https://doi.org/10.32626/2227-6246.2021-53.355-380 
DOI: https://doi.org/10.32626/2227-6246.2021-53

2021. ВИПУСК 53

is minimal, the level of aspirations has a small motivational value, but if Self-inclusion exceeds a certain limit, the level of aspirations becomes a way of protecting of an individual's Self from failure (Сидоров, 2014).

A level of aspirations is closely related to an individual's self-attitude and the motivational tendency to success or to failure avoidance. The effect of success pursuit or failure avoidance was studied for various activities, as well as success or failure influence on an individual's level of aspirations, internal attitudes and perfectionist tendencies ((Fessel, 2010; Stoeber, Hutchfield \& Wood, 2008). It was found that selfattitude changes positively at success; and self-attitude, social interest, and ambitions become lower at failure.

At the young school age, aspirations begin to play a significant role in a child's psychological individuality. Aspirations manifest an individual's numerous attitudes, as well as some fundamental formations, in particular, self-consciousness and its component - the idea of Self, which is actively developing at this age. The discrepancy between aspirations and an individual's abilities, both an overestimation and downplaying, is the result of him/herself misunderstanding and wrong selfestimation. This, in turn, can lead to inappropriate behaviour, emotional breakdowns, increased anxiety, and, subsequently, to deficiencies and defects in personality formation (Чопик, 2012). The problem is particularly important for schoolchildren with low educational achievements. Therefore, one of the aspects of our research on aspirations of schoolchildren with different academic achievements was to study their reactions to success and failure at fulfilment of educational tasks and the possibility of parents' assistance to their children.

The research purpose is to analyze the peculiarities of young schoolchildren's reactions to success or failure if they have different academic achievements. 


\section{The tasks of the research}

1. To characterize the peculiarities of young schoolchildren's reactions to success or failure if they have different academic achievements.

2. To discuss the principles and strategies of effective interactions between parents and children with educational difficulties.

\section{Methods of the research}

In order to investigate reactions to success and failure characteristics of primary school children having different levels of academic achievements, the "Unfinished Sentences" technique was used. The tasks were aimed at updating an experience of success or failure during training. We asked schoolchildren to complete the sentences: "When I successfully complete a task, then I am...» and "When I am unable to cope with a task, then I am...» and examined their reactions to success and failure, and this data, especially their reactions to failure, allowed us to make conclusions about their locus of control, their ability (or inability) to accept responsibility for results of their actions, in particular, results of learning.

The research was attended with 153 children studied at the second - fourth forms of primary school. Depending on their academic achievements, the children were divided into three groups: Group I - children with high academic achievements, Group II - children with average academic achievements, Group III - children with low academic achievements.

\section{Results and their discussion}

Based on the performed content analysis of the endings of the sentence "When I successfully complete a task, then I am...» we divided all received answers into five groups of characteristics (categories).

(C) Yavorska-Vietrova Iryna

DOI (article): https://doi.org/10.32626/2227-6246.2021-53.355-380 
Categories of answers of the second - fourth-form schoolchildren regarding their reactions to success

\begin{tabular}{|c|c|c|}
\hline \multicolumn{2}{|c|}{ Categories } & Illustrative statements \\
\hline \multicolumn{2}{|c|}{$\begin{array}{c}\text { I. Feelings of joy, } \\
\text { satisfaction, self-approval }\end{array}$} & $\begin{array}{l}\text { "glad», «smile», «very happy», «well } \\
\text { done», «I do everything correctly» }\end{array}$ \\
\hline \multicolumn{2}{|c|}{$\begin{array}{c}\text { II. Anxious feelings } \\
\text { about a possible mistake, } \\
\text { perfectionist tendencies }\end{array}$} & $\begin{array}{l}\text { «checking what I did wrong», } \\
\text { "worried to write correctly», «a little } \\
\text { scared», «I want to do even better» }\end{array}$ \\
\hline \multicolumn{2}{|c|}{$\begin{array}{l}\text { III. Orientation } \\
\text { to others' reactions }\end{array}$} & $\begin{array}{l}\text { «feel affection», «my mom will be } \\
\text { happy», «I will be praised» }\end{array}$ \\
\hline \multirow[t]{2}{*}{$\begin{array}{l}\text { IV. Focus } \\
\text { on award }\end{array}$} & $\begin{array}{l}\text { A) getting } \\
\text { a high score }\end{array}$ & $\begin{array}{c}\text { «I will get } 12 », \text { my good mark } \\
\text { will be put into records» }\end{array}$ \\
\hline & $\begin{array}{l}\text { B) getting an } \\
\text { opportunity to } \\
\text { do other things }\end{array}$ & $\begin{array}{l}\text { "I go for a walk», "I can do my } \\
\text { own business», «I play games» }\end{array}$ \\
\hline \multicolumn{3}{|c|}{ V. Undefined answers } \\
\hline
\end{tabular}

The data on the answers distribution for the groups of schoolchildren with different levels of academic achievement are presented in Table 2 .

Table 2

Distribution of the second - fourth-form schoolchildren's answers about their reactions to success depending on the levels of their academic achievements (in \%)

\begin{tabular}{|c|c|c|c|c|c|c|c|}
\hline \multirow{2}{*}{\multicolumn{2}{|c|}{ Groups, forms }} & \multicolumn{6}{|c|}{ Statement categories } \\
\hline & & \multirow{2}{*}{ I } & \multirow{2}{*}{ II } & \multirow{2}{*}{ III } & \multicolumn{2}{|c|}{ IV } & \multirow{2}{*}{$\mathbf{V}$} \\
\hline & & & & & $\mathbf{A}$ & B & \\
\hline \multicolumn{2}{|r|}{1} & 2 & 3 & 4 & 5 & 6 & 7 \\
\hline \multirow{3}{*}{ 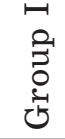 } & II form & 58.3 & - & - & 33.3 & - & 8.3 \\
\hline & III form & 50.8 & 15.8 & - & 9.5 & 23.8 & 4.8 \\
\hline & IV form & 69.1 & 7.2 & 21.4 & 16.7 & - & 7.2 \\
\hline
\end{tabular}

(C) Yavorska-Vietrova Iryna

DOI (article): https://doi.org/10.32626/2227-6246.2021-53.355-380 
DOI: https://doi.org/10.32626/2227-6246.2021-53

2021. ВИПУСК 53

\begin{tabular}{|c|c|c|c|c|c|c|c|}
\hline \multicolumn{2}{|r|}{1} & 2 & 3 & 4 & 5 & 6 & 7 \\
\hline \multirow{3}{*}{ 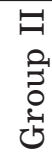 } & II form & 26.9 & - & 3.9 & 31.6 & 7.7 & 29.9 \\
\hline & III form & 67.9 & 7.1 & - & 3.3 & 25.0 & 6.7 \\
\hline & IV form & 56.7 & 23.3 & 6.7 & 3.3 & 13.3 & 3.3 \\
\hline \multirow{3}{*}{ 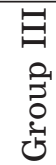 } & II form & - & - & - & 25.0 & - & 75.0 \\
\hline & III form & 56.7 & - & 2.8 & 2.8 & - & 36.1 \\
\hline & IV form & 56.7 & 33.3 & - & - & 27.8 & 22.2 \\
\hline
\end{tabular}

The data analysis shows that the most common reaction to success - and it is a natural reaction - is an emotional experience: joy, satisfaction, pride in oneself, self-acceptance, self-esteem ( «I am great», "I start thinking well about myself»). The percentage of such responses is the highest in all age and achievement groups (Fig. 1).

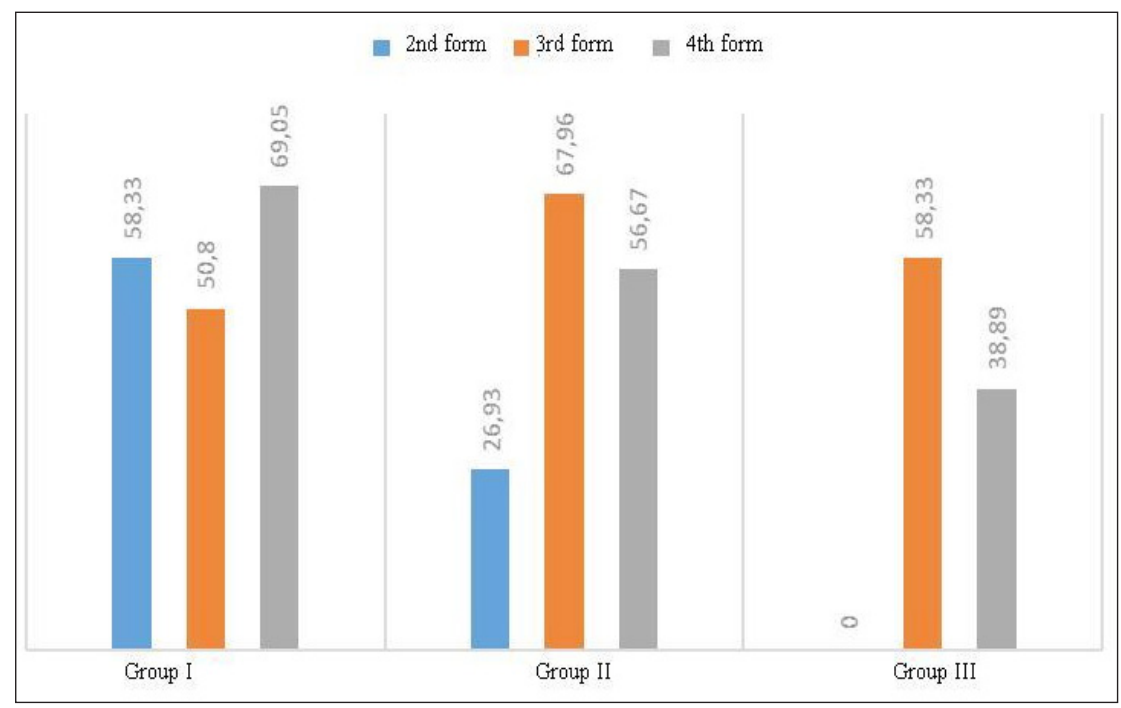

Fig. 1. Expressiveness of positive emotional reactions to success, characteristic for schoolchildren with different academic achievements

(C) Yavorska-Vietrova Iryna 
DOI: https://doi.org/10.32626/2227-6246.2021-53

2021. випуск 53

As for the low-performing schoolchildren from the secondform, they had difficulties in completing this sentence: they did not understand meaning of «successful» world, showed confusion, uncertainty, and embarrassment. This obviously indicates their very little, or even absent, experience of achievements, and it is true not just for learning. Most of their statements $\mathbf{( 7 5 . 0 \% )}$ ) are vague, undifferentiated, "off topic». That is, we can say that some of these children have little experience in success, and therefore do not have motivation to achieve them.

The second most important reaction to success is expectations of rewards - in the form of a high mark or a well-earned rest. Moreover, if statements about assessments were mentioned by virtually all groups (except for low-achieving fourthform schoolchildren), children with average achievements are often oriented onto rest and other out-of-school activities: $7.7 \%$ of the $2^{\text {nd }}$-form children, $25.0 \%$ of the $3^{\text {rd }}$-form children, and $13.3 \%$ of the $4^{\text {th }}$-form children. A significant percentage of such statements were also recorded for the $3^{\text {rd }}$-form children with high achievements $(23.8 \%)$ and the $4^{\text {th }}$-form children with low-achievements $(27.8 \%)$. This may indicate that some children have strong out-of-school priorities, which can become overwhelming against the background of the lowered learning efficiency. At the same time, as conversations showed, out-ofschool activities of children with average achievements are mainly additional lessons, attending children's clubs (sport, dancing, musical), but schoolchildren with low achievements answered that they just "go outside» or «play in computer games».

The orientation onto assessments is most characteristic of the $2^{\text {nd }}$-form children $(33.3 \%$ in Group I, $31.6 \%$ in Group II, $25.0 \%$ in Group III). That is, the assessment of their work by their teacher, socially significant success is one of the important motives at this initial stage of learning. Good marks become even more important to the $4^{\text {th }}$-form children with high achievements (16.7\%). Thus, if teachers and parents orient (C) Yavorska-Vietrova Iryna

DOI (article): https://doi.org/10.32626/2227-6246.2021-53.355-380 
DOI: https://doi.org/10.32626/2227-6246.2021-53

2021. ВИПУСК 53

their children to the end-of-primary-school exams, high marks for current tests become more important for the primary school graduates.

Attention should be drawn to data on anxiety as for possible mistakes, perfectionist tendencies shown by the $3^{\text {rd }}$ and $4^{\text {th }}$-form schoolchildren (the $2^{\text {nd }}$-form children did not mentioned such statements) (Fig. 2).

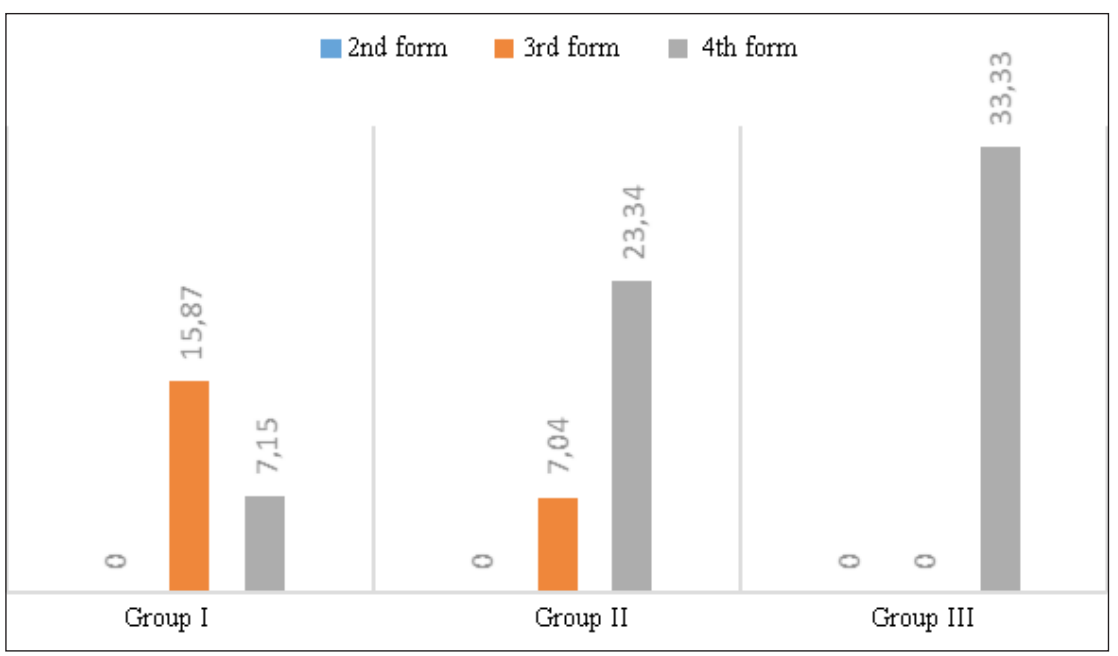

Fig. 2. Negative emotional reactions to success of schoolchildren with different academic achievements

The performed substantive analysis shows that anxiety experiences of the third-fourth-form schoolchildren with average academic achievements are more constructive: they check their work to correct possible mistakes; but schoolchildren with low achievements often experience undifferentiated anxiety: "worrying", "wanting something", "I also feel anxious». Thus, with age and learning experience, children with developed control and self-control skills at learning are less anxious and more constructive about their work. Low-performing children act unconstructively, their self-control skills are

(C) Yavorska-Vietrova Iryna

DOI (article): https://doi.org/10.32626/2227-6246.2021-53.355-380 
DOI: https://doi.org/10.32626/2227-6246.2021-53

2021. ВИПУСК 53

underdeveloped, provoking, even at a success, a «background» undifferentiated anxiety.

The percentage of uncertain reactions to success is quite significant (Fig. 3).

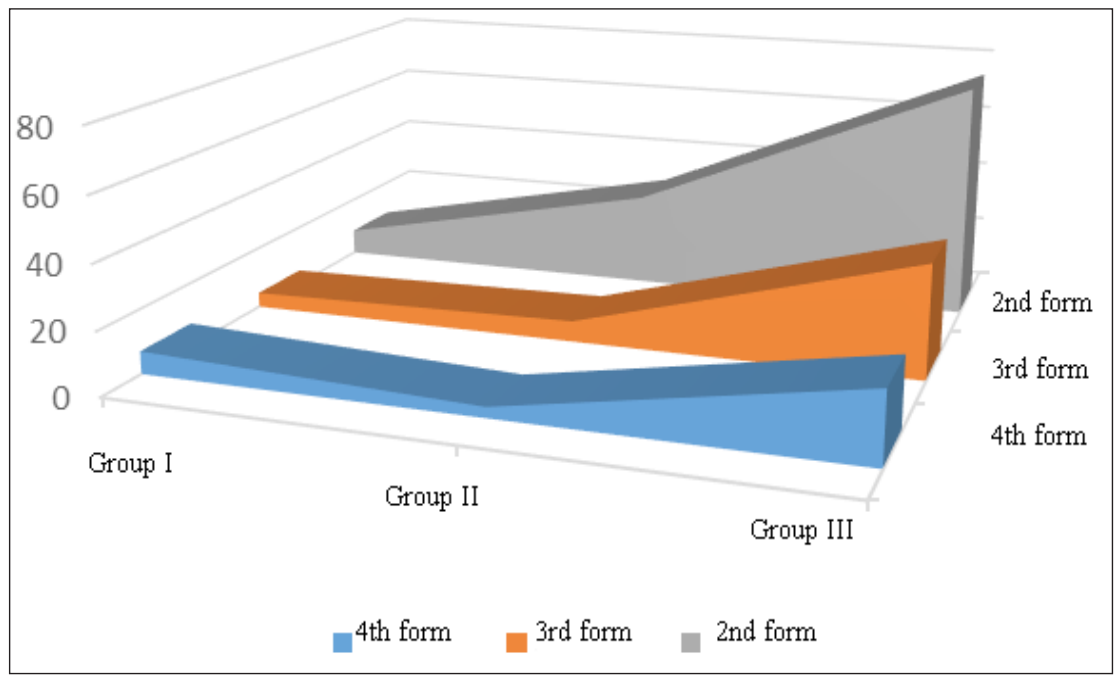

Fig. 3. Dynamics of uncertain reactions to success of schoolchildren with different academic achievements

Moreover, as the above data show, the percentage of such statements increases with academic performance worsening. This confirms the idea that some poorly performing schoolchildren do not have sufficient experience of success, its achieving and experiencing, so they do not know how to respond at the situation of success. And this, in turn, affects their motivational structure, the proportion of motivation to avoid failure rises and motivation for success lowers.

By performing the content analysis of the endings for the sentence "When I cannot cope with a task, then I am...», we divided all received answers into six groups of characteristics (categories).

(C) Yavorska-Vietrova Iryna

DOI (article): https://doi.org/10.32626/2227-6246.2021-53.355-380 
Categories of the answers given by the second-fourth form schoolchildren regarding their reactions to failure

\begin{tabular}{|c|c|c|}
\hline \multicolumn{2}{|c|}{ Categories } & Illustrative statements \\
\hline I. Emotions & A) sadness & $\begin{array}{c}\text { «feel sorrow», «not happy», } \\
\text { «regretful», «crying» }\end{array}$ \\
\cline { 2 - 3 } $\begin{array}{c}\text { B) aggressive } \\
\text { feelings }\end{array}$ & $\begin{array}{c}\text { «angry», "go crazy», «nervous», } \\
\text { «yelling at my mom» }\end{array}$ \\
\hline II. Asking for help & "ask my teacher», «ask mom for help» \\
\hline $\begin{array}{c}\text { III. Statement of error, } \\
\text { indifferent-passive response }\end{array}$ & «crossing out», «admit my mistake» \\
\hline $\begin{array}{c}\text { IV. Refusal to perform } \\
\text { the task }\end{array}$ & $\begin{array}{c}\text { "I do not do this task», } \\
\text { «I refuse to do this» }\end{array}$ \\
\hline $\begin{array}{c}\text { V. Attempts to correct } \\
\text { mistakes, to finish the task }\end{array}$ & $\begin{array}{c}\text { «start over», «trying», «will } \\
\text { rework», «think how to correct», «I } \\
\text { aminking until I find a solution» }\end{array}$ \\
\hline \multicolumn{2}{|c|}{ VI. Indefinite answers } \\
\hline
\end{tabular}

The answer distribution for the groups of schoolchildren with different levels of academic achievement is presented in Table 4.

Table 4

Distribution of the second - fourth-form schoolchildren's statements on their reactions to failure depending on the levels of their academic achievements (in \%)

\begin{tabular}{|c|c|c|c|c|c|c|c|c|}
\hline \multirow{3}{*}{\multicolumn{2}{|c|}{ Groups, forms }} & \multicolumn{7}{|c|}{ Statement categories } \\
\hline & & \multicolumn{2}{|c|}{ I } & \multirow{2}{*}{ II } & \multirow{2}{*}{ III } & \multirow{2}{*}{ IV } & \multirow{2}{*}{$\mathbf{V}$} & \multirow{2}{*}{ VI } \\
\hline & & $\mathbf{A}$ & B & & & & & \\
\hline \multicolumn{2}{|r|}{1} & 2 & 3 & 4 & 5 & 6 & 7 & 8 \\
\hline \multirow{3}{*}{ 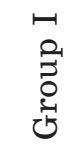 } & II form & 16.7 & 16.7 & 10.0 & 20.0 & - & 18.3 & 18.3 \\
\hline & III form & 19.1 & 38.1 & 14.3 & 9.5 & - & 23.8 & - \\
\hline & IV form & 7.2 & 50.0 & 7.2 & 7.2 & - & 28.6 & 7.2 \\
\hline
\end{tabular}

(C) Yavorska-Vietrova Iryna 
DOI: https://doi.org/10.32626/2227-6246.2021-53

2021. випуск 53

\begin{tabular}{|c|c|c|c|c|c|c|c|c|}
\hline \multicolumn{2}{|r|}{1} & 2 & 3 & 4 & 5 & 6 & 7 & 8 \\
\hline \multirow{3}{*}{ 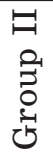 } & II form & 17.9 & 37.7 & 5.6 & 16.7 & - & 25.8 & 5.6 \\
\hline & III form & 27.3 & 29.4 & 7.5 & 15.0 & - & 30.7 & 3.3 \\
\hline & IV form & 23.3 & 16.7 & 23.3 & 10.0 & 6.7 & 26.7 & - \\
\hline \multirow{3}{*}{ 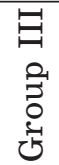 } & II form & - & 50.0 & - & 50.0 & - & - & - \\
\hline & III form & 21.7 & 6.7 & 8.3 & 23.3 & 11.1 & 26.1 & 9.4 \\
\hline & IV form & 11.1 & 22.2 & 5.6 & 11.1 & - & 33.3 & 22.2 \\
\hline
\end{tabular}

The range of reactions to failure is broader -6 categories of statements were identified. In this case, the largest percentage belongs also to emotional reactions, which, however, are divided into two groups: A) sadness (as a more passive, stating reaction to a failure) and B) aggressive feelings and experiences (as a reaction effective, active). Moreover, the second type of reactions appears more often.

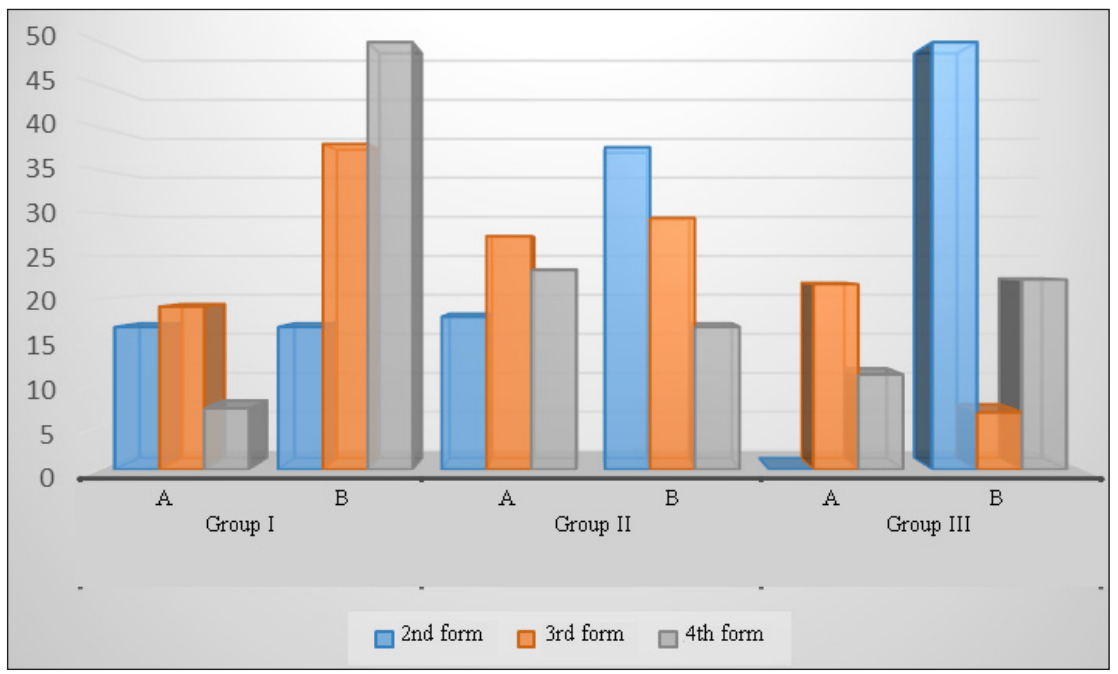

Fig. 4. Expressiveness of emotional reactions to failure characteristic for schoolchildren with different academic achievements

(C) Yavorska-Vietrova Iryna

DOI (article): https://doi.org/10.32626/2227-6246.2021-53.355-380 
Quite significant increase of aggressive reactions was recorded for the second-form schoolchildren from I group to the III group (from high to low academic achievements). The same reactions (anger, nervousness, fury) were most often expressed by the fourth-form children with high academic achievements. Consequently, children who often have failures and are often successful react almost in the same way. That is, children who fail are not able to respond to it properly. In our opinion, the phrase «to be a good looser» is quite relevant for school. After all, development of the ability to analyze and control a situation, to draw conclusions will lead to a more constructive, creative attitude to failures, and will form the ability to overcome them.

From this point of view, it is very encouraging to see the dynamics of the statements expressing efforts to finish a task, to correct mistakes, to make other efforts to succeed (Fig. 5).

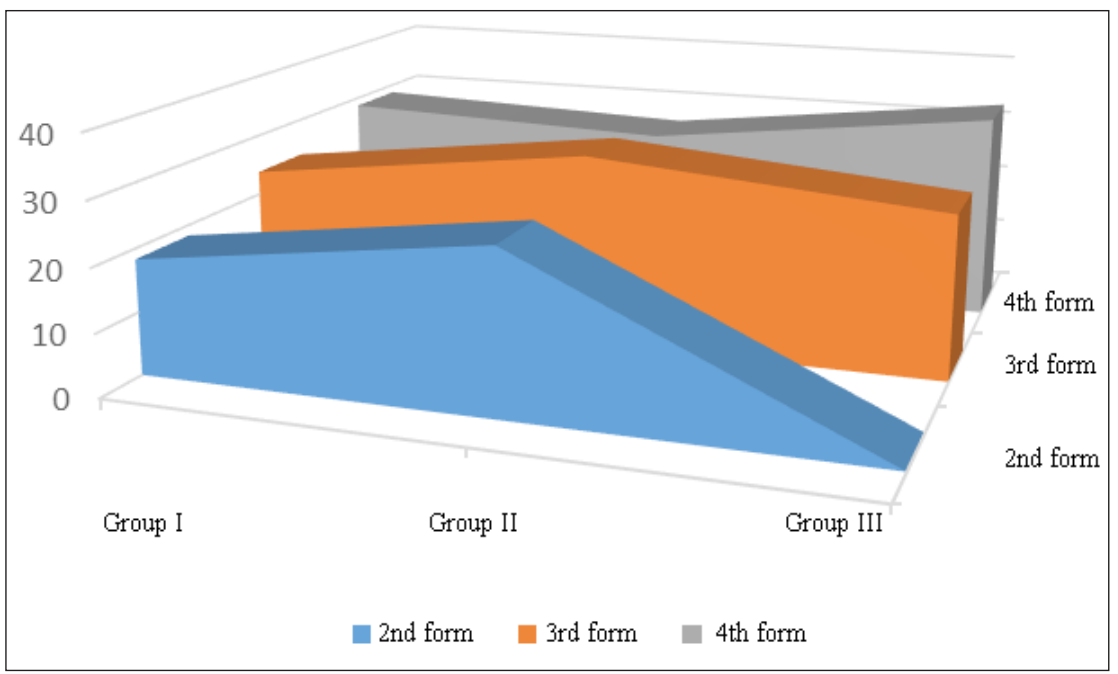

Fig. 5. Dynamics of the number of statements regarding constructive solutions of failure for schoolchildren with different academic achievements

(C) Yavorska-Vietrova Iryna 
DOI: https://doi.org/10.32626/2227-6246.2021-53

2021. випУск 53

This number grows with age (from the $2^{\text {nd }}$ to the $4^{\text {th }}$-form) and is characteristic for practically all groups as for academic achievements (except for the low-achieving second-form children). The percentage of vague statements (compared to the previous data) mainly decreases also, so we can talk about development of children's more constructive behaviour at failure; children begin to focus on effective, active problem solving.

Schoolchildren see one of the solutions at failure that is asking for help to their teacher or parents (that is more often). The percentage of such statements in the obtained data is from $5.6 \%$ to $23.3 \%$ and this result is unstable. That is, we can conclude that asking for help is not a usual way out at a difficult situation, especially for low-achieving schoolchildren $\left(2^{\text {nd }}\right.$-form children did not mention such reaction, $8.3 \%$ of the $3^{\text {rd }}$-form children and $5.6 \%$ of the $4^{\text {th }}$-form children react this manner). Therefore, many children try to cope with the difficulties themselves, without support of adults or peers. By the way, appealing for help to classmates did not sound in any answer. Here, we can see a quite important problem in the dyads of «child - adult» and «schoolchild - other schoolchild». So, in situations of failure, everything depends on good parent-child relationships and a favourable, informal attitude to children of their teacher. This was clearly evident in the performed study: the percentage of asking for help is higher in the forms where teachers adhere to a more democratic, "soft», friendly attitude.

Another way out of a failure is to refuse to complete a task. Such statements were mentioned by the fourth-form children with average achievements $(6.7 \%)$ and the third-form children with low achievements (11.1\%). Such behaviour is characteristic of people with excessive or low levels of aspirations, who, while trying to support their existing «Self», avoid situations of failure as much as possible. This proves once more that low-achieving schoolchildren have motivation to avoid failure, up to the rejection of a proposed activity.

(C) Yavorska-Vietrova Iryna

DOI (article): https://doi.org/10.32626/2227-6246.2021-53.355-380 
The alarming result is that rather high percentage of all statements showed indifferent, passive attitude to failure, there were simple statements of errors: (the $2^{\text {nd }}$-form: $20.0 \%$ at the Group I, 16.7\% at the Group II, 50.0\% at the Group III; the $3^{\text {rd }}$-form: $9.5 \%$ at the Group I, $15.0 \%$ at the Group II, $23.3 \%$ at the Group III; the 4 rd form: $7.2 \%$ at the Group I, $10.0 \%$ at the Group II, $11.1 \%$ at the Group III). As we can see, the highest percentage of such statements is in the low-performing groups in all forms, compared to the high- and average-performing groups. In our opinion, this is another manifestation of a chronic social failure. Children with low academic achievements are unsuccessful for a long period of time as for their learning. Over time, they form a passive attitude to learning, their emotions concerning learning obtain negative colours, learning loses personal significance, and therefore, children do not feel responsible for the results.

The identified peculiarities of primary schoolchildren's reactions to successes and failures depending of their academic achievements show the need to help parents to influence on their children with corrective and developmental aims in order to ensure children's constructive personal development. This view is based on understanding of family as a societal resource based on close relationships, mutual feelings, cooperation and mutual responsibility with the aim to strengthen internal ties and interactions (Bokało \& Koperek, 2014). The key task of such influences and interactions is to create an «image of subjectivity", which is reflected in certain aspects of activity, such as: the conditionality of the mental image of past experiences, needs, attitudes, emotions, goals and motives that determine controllability and selectivity (Терновик \& Славіна, 2020).

In addition to work directly with schoolchildren, counselling was proposed for their parents, which included acquaintance with the schoolchildren's age and psychological characteristics identified during the performed experimental study;

(C) Yavorska-Vietrova Iryna

DOI (article): https://doi.org/10.32626/2227-6246.2021-53.355-380 
DOI: https://doi.org/10.32626/2227-6246.2021-53

2021. випуСК 53

analysis of various situations of parent-child relationships; discussion of problematic issues appeared because of existing differences between parents' ideas about an «ideal schoolchild" and the real child. After all, researchers have proved that a constructive solution to contradictions reduces the frustrating load, strengthens the strength of the self, the transition to a new level of personal development (Vovk, Emishyants, Zelenko, Drobot \& Onufriieva, 2020).

The basic principles that should use parents having schoolchildren with different academic achievements are the following (Вологодина, 2008; Сартан, 1998):

Try to keep a positive picture on your children. Believe that your child is positive, responsible, kind and that he/she, like everyone else, wants justice, love, mutual help in his/her life. Tell the child whom you would like to see him/her and what you would like to achieve when interacting with him/her.

Learn to keep your goals in mind. When experiencing difficulties in dealing with your child, remember that your main goal is to be happy and to see that your child is a responsible and respectful person. Despite failures, remember what you are really striving for, which is the ultimate goal of your actions towards your child.

Try to change your attitude. Take responsibility for creating a dominant mood or atmosphere in a relationship with your child and do not allow yourself to be involved in the «Who Wins?» game. Remember that only a positive attitude towards your child will have a positive effect on the problem that exists between you and him/her.

Think of relationship levels. Make a Declaration of Parents' Rights for yourself and decide to protect it. This declaration can take the following form: «My child and I - as individuals have equal rights. My child is responsible for taking care of his/her needs and his/her happiness, and I am responsible for taking care of his/her needs and his/her happiness. My main task is to remain faithful to my inner self. In doing so, I will (C) Yavorska-Vietrova Iryna

DOI (article): https://doi.org/10.32626/2227-6246.2021-53.355-380 
also benefit those around me. The best I can give my children is an example of the fact that it is quite possible to take care of own feelings, ideas and be happy".

Determine your rights. If you decide to have more equal relationships with your child, then you should determine your rights and begin to assert them. For example, it is possible to state such rights: "Right to be alone. Right to have personal time. Right to respectful treatment. The right to equal relationships. Right to be free from the fear of violence. Right to normal, reasonable peace and quiet. Right to feel safe about property». Parents must make sure their children's rights are equivalent to what parents have, so that the relationships are truly equal.

Discussions were held with parents of low-efficient children named the "Rules of safe making of assessments». Primary school children with any degree of school failure need «psychotherapy against failure», aimed at emotional overcoming of a traumatic situation, reducing of failure, changing of children's attitudes to learning, their capabilities and perspectives. Its basic rules are the following (Цукерман, 1994):

«Rule One: Do not beat the one who lie». Bad mark is enough punishment and you should not punish twice for the same mistake.

«Rule Two: Mention no more than one drawback at a time to overcome it». Whenever possible, you should choose only one drawback of your child, and talk only about it. All others will then be overcome later or will become unimportant.

«Rule Three: Not all at one». When you do not know where to start, consult with your child and begin addressing the learning problems that are the most important to him/her.

«Rule Four and central: praise the performer, but criticize the execution». Children are inclined to perceive any assessment globally and think that their entire personality and all work are evaluated. They need to be helped to separate assessments of their personality from evaluations of their work. A (C) Yavorska-Vietrova Iryna 
DOI: https://doi.org/10.32626/2227-6246.2021-53

2021. випуск 53

positive assessment should be addressed to a schoolchild to help him/her become better and more skilled. But along with such personal praise, criticism should be as impersonal as possible. This form of a negative evaluation stimulates error correction but does not affect the child's attitude to schoolwork, his/her belief in self-power and success in activities.

«Rule Five, the hardest one: an assessment should compare a child's success today with his/her own yesterday's failure, not just with the state assessment norms and not the results of other children». Even the smallest success of a child is a real success, a victory over him/herself, and he/she must be judged on his/her merits.

«Rule Six: Be generous with your praise». It must be remembered that there are already a child's qualities that should be praised, and they will not appear later as a result of systematic trainings and work on him/herself. And this should be reflected in assessments made today.

«Rule Seven, dedicated to the art of finding, in a sea of errors, an island of success where a child's faith in him/herself and his/her learning success may take root». At differentiated assessments, children have neither an illusion of complete success nor the feeling of complete failure. There is a business motivation: I do not know yet, but I can and want to know. Parents may replace the school marking with a finer one, such as a hundred-mark scale. Or, they may evaluate separately each academic skill, knowledge of one rule, cleanliness of execution, attentiveness, accuracy of handwriting, etc.

«Rule Eight: Set of specific and realistic goals for your child, and he/she will strive to achieve them». Excessive, unattainable goals can push a child into the path of deception, lower self-esteem, and undermine his/her self-belief and his/her potential for success.

«Rule Nine, making all the previous ones effective: a child should not be an object, but a co-partner in assessments, and (C) Yavorska-Vietrova Iryna

DOI (article): https://doi.org/10.32626/2227-6246.2021-53.355-380 
he/she should be taught to evaluate own achievements». The ability to evaluate oneself is a necessary component of the ability to learn - the main means for overcoming of learning difficulties.

\section{Conclusions}

The study of such a psychological phenomenon as the level of aspirations at different ages, and especially at primary school age, is of particular importance. This is necessary to develop individualised tactics of psychological influences and thereby to promote each child's harmonious personal growth. Differences between aspirations and opportunities, success or failure in different activities have a significant impact on a child's perception of his/herself, his/her self-assessment, and also on effectiveness of his/her activities, in particular, his/ her learning. Our research has determined that children experiencing academic failure for a long time become indifferent to learning, their emotions toward learning become negative, learning loses personal significance, and therefore, children do not feel responsible for own academic results.

Taking into account the individual and group characteristics of primary school children with different academic achievements, reliance on the above-mentioned principles and rules of interactions will allow teachers and psychologists to choose optimal forms and methods of corrective work with such children and their parents.

\section{Literature}

Бороздина Л.В. Уровень притязаний: классические и современные исследования. Москва : Акрополь, 2011. 322 с.

Вологодина Н.В. Тренинг самостоятельности у детей. Ростов-на-Дону : Феникс, 2006. 240 с.

Дмитрієва С.М., Бутузова Л.П. Психологічні особливості самооцінки та рівня домагань старшокласників. Наука $і$ освіта, 2016, 5, 166171. URL : https://doi.org/10.24195/2414-4665-2016-5-26.

(C) Yavorska-Vietrova Iryna

DOI (article): https://doi.org/10.32626/2227-6246.2021-53.355-380 
DOI: https://doi.org/10.32626/2227-6246.2021-53

2021. випуск 53

Зинько Е.В. Соотношение характеристик самооценки и уровня притязаний. Уровень притязаний и варианты его сочетаний с самооценкой. Психологический журнал, 2006, 27, 4 (2), 15-25.

Меднікова Г.І. Самооцінка та рівень домагань особистості як динамічна система: автореф. дис. ... канд. психол. наук: 19.00.01. Одеса, 2002. $22 \mathrm{c}$.

Сартан Г.Н. Тренинг самостоятельности у детей. Москва : Творческий центр «Сфера», 1998. 235 с.

Сидоров К.Р. Концепт «уровень притязаний» в современной психологии. Вестник Удмуртского университета. Философия. Психология. Педагогика, 2014, 2, 40-50. URL : https://cyberleninka.ru/ article/n/kontsept-uroven-prityazaniy-v-sovremennoy-psihologii/ viewer.

Терновик Н., Славіна Н. Психологічний тренінг розвитку суб'єктності особистості в підлітковому віці. Збірник наукових пращь «Проблели сучасної психологї̈, $2020,48,272-292$. URL : https://doi.org/ 10.32626/2227-6246.2020-48.272-292.

Ушакова І.М., Курбанов М.Ю. Особливості самооцінки та рівня домагань у курсантів та студентів НУЦЗУ з різною успішністю учбової діяльності. Проблеми екстремальної та кризової психологї, 2011, 10, 247-254. URL : https://nuczu.edu.ua/sciencearchive/ ProblemsOfExtremeAndCrisisPsychology/vol10/032.pdf.

Цукерман Г.А. Школьные трудности благополучных детей. Учился читать и писать. Москва : Знание, 1994. С. 86-160.

Чопик С.В. Розвиток рівня домагань як передумова становлення особистості молодшого школяра. Збірник наукових праць «Проблели сучасної психологї̈, 2012, 15, 760-770. URL : http://eehb.dspu. edu.ua/index.php/2227-6246/article/view/160744/159959.

Bokało, W., \& Koperek, J. The Family as a Resource for Civil Society. Roczniki Teologiczne.Zeszyt 10: Nauki o rodzinie, 2014, LXV, 61 (10), 7-20. URL : https://ojs.tnkul.pl/index.php/rt/article/view/7094/ 8185.

Fessel, F. Increasing Level of Aspiration by Matching Construal Level and Temporal Distance. Social Psychological and Personality Science, 2010, 2 (1), 103-111. URL : https://doi.org/10.1177/1948550610381788. Janke, S., \& Dickhäuser, O. A neglected tenet of achievement goal theory: Associations between life aspirations and achievement goal orientations. Personality and Individual Differences, 2019, 142 (1), 90-99. URL : https://doi.org/10.1016/j.paid.2019.01.038.

Król, J. The Present Situation and the Idea of Personalistic Education. Roczniki Teologiczne. Zeszyt 10: Nauki o rodzinie, 2014, LXV, 61 (10), (c) Yavorska-Vietrova Iryna

DOI (article): https://doi.org/10.32626/2227-6246.2021-53.355-380 http://journals.uran.ua/index.php/2227-6246 
21-34. URL : https://ojs.tnkul.pl/index.php/rt/article/view/8507/ 8186.

Maksymenko, S., \& Serdiuk, L. Psychological Potential of Personal Selfrealization. Social Welfare: Interdisciplinary Approach, 2016, 6 (1), 92-100. URL : http://dx.doi.org/10.21277/sw.v1i6.244.

Stoeber, J., Hutchfield, J., \& Wood, K. V. Perfectionism, self-efficacy, and aspiration level: differential effects of perfectionistic striving and self-criticism after success and failure. Personality and Individual Differences, 2008, 45 (4), 323-327. URL : https://doi.org/ 10.1016/j.paid.2008.04.021.

Vovk, M., Emishyants, O., Zelenko, O., Drobot, O., \& Onufriieva, L. Psychological Features of Experiences of Frustration Situations in Youth Age. International Journal of Scientific \& Technology Research, 2020, 8 (1), 920-924. URL : http://www.ijstr.org/paperreferences.php?ref=IJSTR-0120-28117.

\section{References}

Borozdina, L.V. (2011). Uroven pritiazanii: klassicheskiie i sovremennyie issledovaniia [Level of aspirations: classical and modern studies]. Moskva : Akropol [in Russian].

Vologodina, N.V. (2006). Trening samostoiatelnosti u detei [Independence training for children]. Rostov-na-Donu : Feniks [in Russian].

Dmytriieva, S.M., \& Butuzova, L.P. (2016). Psykholohichni osoblyvosti samootsinky ta rivnia domahan starshoklasnykiv [Psychological characteriatics of senior school students' self-appraisal and the level of aspirations]. Nauka i osvita - Science and education, 5, 166-171. Retrieved from https://doi.org/10.24195/2414-4665-2016-5-26 [in Ukrainian].

Zinko, E.V. (2006). Sootnosheniie kharakteristik samootsenki i urovnia pritiazanii. Uroven pritiazanii i varianty ego sochetanii s samootsenkoi [The ratio of the characteristics of self-esteem and the level of aspirations. The level of aspirations and options for combining it with self-esteem]. Psikhologicheskii zhurnal-Psychological journal, 27, 4 (2), 15-25 [in Russian].

Mednikova, H.I. (2002). Samootsinka ta riven domahan osobystosti yak dynamichna systema [Self-esteem and the level of individual aspirations as a dynamic system]. Extended abstract of candidate's thesis. Odesa [in Ukrainian].

Sartan, G.N. (1998). Trening samostoiatelnosti u detei [Independence training for children]. Moskva : Tvorcheskii tsentr «Sfera» [in Russian].

(C) Yavorska-Vietrova Iryna

DOI (article): https://doi.org/10.32626/2227-6246.2021-53.355-380 
DOI: https://doi.org/10.32626/2227-6246.2021-53

2021. випуск 53

Sidorov, K.R. (2014). Kontsept «uroven pritiazanii» v sovremennoi psikhologii [The concept of «level of aspirations» in modern psychology]. Vestnik Udmurtskogo universiteta. Filosofiia. Psikhologiia. Pedagogika - Bulletin of the Udmurt University. Philosophy. Psychology. Pedagogy, 2, 40-50. Retrieved from https://cyberleninka.ru/article/ $\mathrm{n} /$ kontsept-uroven-prityazaniy-v-sovremennoy-psihologii/viewer [in Russian].

Ternovyk Nataliia, \& Slavina, Nataliia (2020). Psykholohichnyi treninh rozvytku subiektnosti osobystosti v pidlitkovomu vitsi [Psychological Training of the Development of Personality's Subjectivity at Adolescence]. Zbirnyk naukovykh prats «Problemy suchasnoi psykholohii, 48, 272-292. Retrieved from https://doi.org/10.32626/22276246.2020-48.272-292 [in Ukrainian].

Ushakova, I.M., \& Kurbanov M.Yu. (2011). Osoblyvosti samootsinky ta rivnia domahan $\mathrm{u}$ kursantiv ta studentiv NUTsZU z riznoiu uspishnistiu uchbovoi diialnosti [Features of self-esteem and the level of aspirations of cadets and students of NUTsZU with different academic achievements]. Problemy ekstremalnoi ta kryzovoi psykholohii - Problems of extreme and crisis psychology, 10, 247-254. Retrieved from https://nuczu.edu.ua/sciencearchive/ProblemsOf ExtremeAndCrisisPsychology/vol10/032.pdf [in Ukrainian].

Tsukerman, G.A. (1994). Shkolnyie trudnosti blagopoluchnykh detei [School difficulties of prosperous children]. Uchimsia chitat i pisat We study to read and write, (pp. 86-160). Moskva : Znaniie [in Russian].

Chopyk, S.V. (2012). Rozvytok rivnia domahan yak peredumova stanovlennia osobystosti molodshoho shkoliara [Development of the level of aspirations as a prerequisite for the formation of the personality of a junior pupil]. Zbirnyk naukovykh prats «Problemy suchasnoi psykholohii», 15, 760-770. Retrieved from http://eehb.dspu.edu.ua/ index.php/2227-6246/article/view/160744/159959 [in Ukrainian].

Bokało, W., \& Koperek, J. (2014). The Family as a Resource for Civil Society. Roczniki Teologiczne. Zeszyt 10: Nauki o rodzinie, LXV, 61 (10), 7-20. Retrieved from https://ojs.tnkul.pl/index.php/rt/article/ view/7094/8185.

Fessel, F. (2010). Increasing Level of Aspiration by Matching Construal Level and Temporal Distance. Social Psychological and Personality Science, 2 (1), 103-111. Retrieved from https://doi.org/10.1177/ 1948550610381788.

Janke, S., \& Dickhäuser, O. (2019). A neglected tenet of achievement goal theory: Associations between life aspirations and achievement

(C) Yavorska-Vietrova Iryna

DOI (article): https://doi.org/10.32626/2227-6246.2021-53.355-380 http://journals.uran.ua/index.php/2227-6246 
goal orientations. Personality and Individual Differences, 142 (1), 90-99. Retrieved from https://doi.org/10.1016/j.paid.2019.01.038. Król, J. (2014). The Present Situation and the Idea of Personalistic Education. Roczniki Teologiczne. Zeszyt 10: Nauki o rodzinie, LXV, 61 (10), 21-34. Retrieved from https://ojs.tnkul.pl/index.php/rt/article/ view $/ 8507 / 8186$.

Maksymenko, S., \& Serdiuk, L. (2016). Psychological Potential of Personal Self-realization. Social Welfare: Interdisciplinary Approach, 6 (1), 92-100. Retrieved from http://dx.doi.org/10.21277/sw.v1i6.244.

Stoeber, J., Hutchfield, J., \& Wood, K. V. (2008). Perfectionism, selfefficacy, and aspiration level: differential effects of perfectionistic striving and self-criticism after success and failure. Personality and Individual Differences, 45 (4), 323-327. Retrieved from https://doi. org/10.1016/j.paid.2008.04.021.

Vovk, M., Emishyants, O., Zelenko, O., Drobot, O., \& Onufriieva, L. (2020). Psychological Features of Experiences of Frustration Situations in Youth Age. International Journal of Scientific \& Technology Research, 8 (1), 920-924. Retrieved from http://www.ijstr.org/ paper-references.php?ref=IJSTR-0120-28117.

Яворська-Ветрова Ірина. Особливості реакцій на успіх і неуспіх молодших школярів у навчальній діяльності

\section{АНОТАЦІЯ}

Мета дослідження - аналіз особливостей вияву реакцій на успіх і неуспіх молодших школярів із різними рівнями навчальних досягнень.

Метод дослідження. Із метою дослідження особливостей вияву реакцій на успіх і неуспіх молодших школярів із різними рівнями навчальних досягнень було використано методику "Незакінчені речення». Дослідження проводилося з учнями других-четвертих класів школи. Залежно від результативності навчальної діяльності учні були поділені на три групи: з високим, середнім і низьким рівнями навчальних досягнень.

Результати дослідження. Констатовано, що найпоширенішою реакцією на успіх є позитивне емоційне переживання й очікування винагороди. Доведено, що учні з низькими навчальними досягненнями навіть у разі успіху діють неконструктивно, їх навички самоконтролю розвинені недостатньо, що провокує «фонову», недиференційовану тривожність. З’ясовано, що школярі, які мають переважно постійний неуспіх (із низьким рівнем навчальних досягнень) або постійний успіх (із високим рівнем

(C) Yavorska-Vietrova Iryna

DOI (article): https://doi.org/10.32626/2227-6246.2021-53.355-380 
навчальних досягнень), у ситуації неуспіху реагують майже однаково: збільшенням негативних, зокрема агресивних, реакцій. Водночас, зі збільшенням віку дітей, зафіксовано становлення більш конструктивної поведінки школярів у ситуаціях неуспіху, появу орієнтації на дійове, активне вирішення проблем. Обгрунтовано доцільність залучення батьків до системи корекційних і розвивальних впливів на дитину з метою забезпечення ії конструктивного особистісного становлення. Запропоновано принципи і правила ефективної батьківсько-дитячої взаємодії.

Висновки. Вивчення такого психологічного феномену, як рівень домагань, на різних вікових етапах, а особливо у молодшому шкільному віці, має особливе значення. Це необхідно для того, щоб максимально індивідуалізувати тактику психологічних впливів і тим самим сприяти гармонійному особистісному зростанню кожної дитини. Розходження між домаганнями і можливостями, успіх чи неуспіх у різних сферах діяльності справляють значний вплив на уявлення дитини про власне $Я$, ії оцінку себе, а також на результативність ії діяльності, зокрема учіннєвої. Установлено, що у школярів, які впродовж тривалого періоду переживають невдачі в навчанні, з часом формується байдуже ставлення до чієї діяльності, вона набуває негативного емочійного забарвлення, втрачає особистісну значущість, а отже, втрачається відповідальність за їі результати. Урахування індивідуальних і групових особливостей реагування на успіх і неуспіх молодших школярів із різним рівнем навчальних досягнень, опора на зазначені вище принципи та правила взаємодії дозволять вибрати оптимальні форми і методи корекційної роботи з учнями цієї вікової групи та їх батьками.

Ключові слова: молодші школярі, рівні навчальних досягнень, реакція на успіх / неуспіх, батьки, батьківсько-дитяча взаємодія.

\section{Яворская-Ветрова Ирина. Особенности реакций на успех и неуспех младших школьников в учебной деятельности}

\section{АННОТАЦИЯ}

Цель исследования - анализ особенностей проявления реакций на успех и неуспех младших икольников с разными уровнями учебных достижений.

Метод исследования. С целью исследования особенностей проявления реакций на успех и неуспех младших школьников с разными уровнями учебных достижений использована методика "Незаконченные пред(C) Yavorska-Vietrova Iryna

DOI (article): https://doi.org/10.32626/2227-6246.2021-53.355-380 
ложения». Исследование проводилось с учащимися вторых-четвертых классов школы. В зависимости от результативности учебной деятельности учащиеся были распределены на три группы: с высоким, средним и низким уровнями учебных достижений.

Результаты исследования. Констатировано, что наиболее распространенной реакцией на успех является позитивное эмоциональное переживание и ожидание награды. Доказано, что учащиеся с низкими учебными достижениями даже в случае успеха действуют неконструктивно, их навыки самоконтроля развиты недостаточно, что провоцирует появление «фоновой», недифференцированной тревожности. Выяснено, что школьники, имеющие постоянный неуспех (с низким уровнем учебных достижений) или постоянный успех (с высоким уровнем учебных достижений), в ситуации неуспеха реагируют почти одинаково: увеличением негативных, в частности агрессивных, реакций. В то же время с увеличением возраста детей зариксировано становление более конструктивного поведения школьников в ситуациях неуспеха, появление ориентации на активное решение проблем. Обосновано целесообразность привлечения родителей к системе коррекционных и развивающих влияний на ребенка с целью обеспечения его конструктивного личностного становления. Предложены принципы и правила эффрективного родительско-детского взаимодействия.

Выводы. Изучение такого психологического френомена, как уровень притязаний, на разных возрастных этапах, а особенно в младшем школьном возрасте, имеет особенное значение. Это необходимо для максимальной индивидуализации тактики психологических влияний и способствования гармоничному личностному росту каждого ребенка. Расхождения между притязаниями и возможностями, успех или неуспех в различных срерах деятельности оказывают значительное влияние на представления ребенка о собственном Я, его оценку себя, а также на результативность деятельности, в частности учебной. Установлено, что у школьников, переживающих неуспехи в обучении на протяжении длительного периода времени, формируется равнодушное отношение к этой деятельности, она приобретает негативную эмоциональную окраску, теряет личностную значимость, а значит, снижается ответственность за ее результаты. Учет индивидуальных и групповых особенностей реагирования на успех и неуспех младших школьников с разными уровнями учебных достижений, опора на указанные принципы и пра-

(c) Yavorska-Vietrova Iryna

DOI (article): https://doi.org/10.32626/2227-6246.2021-53.355-380 
DOI: https://doi.org/10.32626/2227-6246.2021-53 2021. ВИПУСК 53

вила взаимодействия позволят избрать оптимальные формы и методы коррекционной работы с учащимися этого возраста и их родителями.

Ключевые слова: младшие школьники, уровни учебных достижений, реакция на успех / неуспех, родители, родительско-детское взаимодействие.

Original manuscript received April 07, 2021 Revised manuscript accepted April 27, 2021 